NBER WORKING PAPER SERIES

\title{
A META-ANALYSIS OF THE EFFECT OF COMMON CURRENCIES ON INTERNATIONAL TRADE
}

\author{
Andrew K.Rose \\ Working Paper 10373 \\ http://www.nber.org/papers/w10373 \\ NATIONAL BUREAU OF ECONOMIC RESEARCH \\ 1050 Massachusetts Avenue \\ Cambridge, MA 02138 \\ March 2004
}

I thank Justin Wolpers, conference/seminar participants at Fordham, Harvard, and the MAS, and especially Tom Stanley for helpful comments. This is an extensive revision of an earlier paper with the same title. The data set, sample output, and a current version of the paper are available at my website. URL: http://faculty.haas.berkeley.edu/arose. The views expressed herein are those of the authors and not necessarily those of the National Bureau of Economic Research.

(C)2004 by Andrew K.Rose. All rights reserved. Short sections of text, not to exceed two paragraphs, may be quoted without explicit permission provided that full credit, including (C) notice, is given to the source. 
A Meta-Analysis of the Effect of Common Currencies on International Trade Andrew K. Rose

NBER Working Paper No. 10373

March 2004

JEL No. F34

\title{
$\underline{\text { ABSTRACT }}$
}

Thirty-four recent studies have investigated the effect of currency union on trade, resulting in 754 point estimates of the effect. This paper is a quantitative attempt to summarize the current state of debate; meta-analysis is used to combine the disparate estimates. The chief findings are that: a) the hypothesis that there is no effect of currency union on trade can be rejected at standard significance levels; b) the combined estimate implies that a bilateral currency union increase trade by between $30 \%$ and $90 \%$; and c) the estimates are heterogeneous and not consistently tied to most features of the studies.

\author{
Andrew K. Rose \\ Haas School of Business \\ University of California \\ Berkeley, CA 94720 \\ and NBER \\ arose@haas.berkeley.edu
}


This short paper reviews the recent literature that estimates the effect of common currencies on trade. Meta-analysis is used to provide a quantitative summary of the literature.

The next section briefly reviews the literature qualitatively. Section 2 is the heart of the paper; it provides the quantitative meta-analysis that studies the preferred point estimates of the thirty-four different studies collectively. Section 3 reviews the (over seven hundred) different point estimates tabulated in the literature, while a section on publication bias follows. The paper ends with a short conclusion.

\section{1: A Short History of the Literature}

In the summer of 1999 , I began to circulate a paper that estimated the effect of currency union on trade; Economic Policy subsequently published this paper in 2000. This paper exploited a panel of cross-country data covering bilateral trade between 186 “countries" (really different trading partners) at five-year intervals between 1970 and 1990. Since most of the variation is across pairs of countries rather than time, I used a conventional "gravity" model of trade to account for factors that drive trade (other than monetary arrangements). This equation has now become the standard vehicle for the literature, and takes the form:

$$
\mathrm{T}_{\mathrm{ijt}}=\beta_{1} \mathrm{D}_{\mathrm{ij}}+\beta_{2}\left(\mathrm{Y}_{\mathrm{i}} \mathrm{Y}_{\mathrm{j}}\right)_{\mathrm{t}}+\Sigma_{\mathrm{k}} \beta_{\mathrm{k}} \mathrm{Z}_{\mathrm{ijt}}+\Sigma_{\mathrm{t}} \mathrm{d}_{\mathrm{t}} \mathrm{T}_{\mathrm{t}}+\gamma C \mathrm{U}_{\mathrm{ijt}}+\mathrm{u}_{\mathrm{ijt}}
$$

where: $\mathrm{T}_{\mathrm{ijt}}$ denotes the natural logarithm of trade between countries $\mathrm{i}$ and $\mathrm{j}$ at time $\mathrm{t},\{\beta\}$ is a set of nuisance coefficients, $D_{i j}$ denotes the $\log$ of distance between $\mathrm{i}$ and $\mathrm{j}, \mathrm{Y}$ denotes 
the log of real GDP, $\mathrm{Z}$ denotes other controls for bilateral trade, $\mathrm{CU}_{\mathrm{ijt}}$ is a dummy variable that is one if countries $i$ and $j$ are in a currency union at $t$ and zero otherwise, and $\mathrm{u}$ is a well-behaved disturbance term. The coefficient of interest is $\gamma$, which represents the partial effect of currency union on trade, ceteris paribus.

In the original study, the trade data was drawn from the World Trade Data Bank ("WTDB"), which contains data for a large number of country-pairs (the reby effectively rendering the analysis cross-sectional), though with many missing observations. In this data set, only a small number of the observations are currency unions; further, countries in currency unions tend to be either small or poor (or both).

The surprising and interesting finding was that currency union seemed to have a strong and robust effect on trade. Even using the standard linear gravity model that accounts for most variation in trade patterns, my point estimate was that the coefficient for a currency union dummy variable (which is unity when a pair of countries share a common currency and zero otherwise) has a point estimate of around $=1.21$. This implies that members of currency unions traded over three times as much as otherwise similar pairs of countries ceteris paribus, since $\exp (1.21)>3$. While there was no benchmark from the literature, this estimate seemed implausibly large to me (and many others). ${ }^{1}$ Almost all the subsequent research in this area has been motivated by the belief that currency union cannot reasonably be expected to triple trade.

There have been a number of different types of critique. Some are econometric. For instance, Thom and Walsh (2002) argue that broad panel studies are irrelevant to many questions of interest, since most currency unions historically have involved countries that are either small or poor. They adopt a case study approach, focusing on the 
1979 dissolution of Ireland's sterling link; Glick and Rose (2002) provide related evidence.

Others have stressed the importance of relying on time-series rather than crosssectional variation. The time-series approach has the advantage of addressing the relevant policy issue ("What happens to trade when a currency union is created or dissolved?" rather than "Is trade between members of currency unions larger than trade between countries with sovereign currencies?"). This can be done most obviously by using country-pair specific "dyadic fixed effects" with panel data. This is difficult to do sensibly using the WTDB because there is such little time-series variation in currency union membership after 1970 as recognized in my original paper and by e.g., Persson (2001); nevertheless, see Pakko and Wall (2001). However, Glick and Rose (2002) exploit the almost 150 cases of currency union exit and entry they find when the panel analysis is extended back to 1948 using the IMF's Direction of Trade data set. See also Fidrmuc and Fidrmuc (2003).

Much of the obsession with the time-series approach (and indeed with the whole area) is concerned with the potential trade effect of Economic and Monetary Union in Europe (EMU). When the area started, the Euro had not been physically introduced. But EMU technically began in 1999, and there is even some trade data since the euro began to circulate in 2002. This more recent data has driven the work of a variety of scholars, including: Barr et al (2003), Bun and Klaassen (2002), de Nardis and Vicarelli (2002), de Souza (2002), and Flam and Nordström, Micco et al (2003). While much of this work might seem premature given the paucity of data from the EMU era, it addresses an issue 
of compelling policy interest, especially given the debates over EMU-entry of Sweden and the UK.

In my original paper, I stressed that only about $1 \%$ of the sample involves pairs of countries in currency unions. Persson (2001) argues that this makes standard regression techniques inappropriate since currency unions are not created randomly, and advocates the use of matching techniques; see also Rose (2001), Tenreyro (2001), and Kenen (2002).

Nitsch (2002a, 2002b) is concerned with aggregation bias, and argues that combining different currency unions masks heterogeneous results. Along the same lines, Levy Yeyati (2003) divides currency unions into multilateral and unilateral currency unions (as did Fatás and Rose, 2001), while Melitz (2001) splits currency unions into those that are also members of either a political union or regional trade area, and others that are neither; see also Klein (2002). Saiki (2002) dis-aggregates total trade into exports and imports.

Tenreyro (2001) argues that sampling the data every fifth year (as I did in my original paper) is dangerous, since trade between members of currency unions may not be large enough to be consistently positive. She advocates averaging trade data over time, and argues that this reduces the (otherwise biased) effect of currency union on trade. While this may be true with the $W T D B$ data set employed by Tenreyro, it seems not to be true of the DoT data set, where no bias is apparent (see my website for details).

Rather than focusing on post-WWII data, some have extended the data set back to the classical gold standard era. Flandreau and Maurel (2001) and López-Córdova and Meissner (2003) use data sets that include monetary unions from the pre-WWI period. 
Estevadeoral, Frantz, and Taylor (2003) estimate a lower bound on the currency union effect by using membership in the gold standard; the inclusion of their estimates imparts a slight downward bias to the meta-analysis below.

A number of researchers have followed my original paper in worrying about reverse causality, including Alesina, Barro and Tenreyro (2003), Bomberger (2002) Flandreau and Maurel (2001), López-Córdova and Meissner (2003), Smith (2002), and Tenreyro (2001); see also Nitsch (2002c). ${ }^{2}$ It is possible to also to take a more structural approach as I do in my work with van Wincoop (2001), which also takes account of country-specific effects.

Finally, some research takes a big effect of currency union on trade as given, and seeks to determine the implications of this estimate for e.g., output (Frankel and Rose, 2002) or business cycle co-ordination (Flandreau and Maurel, 2001). Other aspects of the behavior of currency union members are examined by Rose and Engel (2002) and Fatás and Rose (2001). Indeed, in their critique of Rose (2004), Subramanian and Wei (2003) are not directly concerned with currency unions at all; they simply include it as another quantifiable cause of trade.

In all, a number of papers have provided estimates of the effect of currency union on international trade. Obviously many these estimates are highly dependent; they sometimes rely on the same data set, techniques, or authors. Still, there seem to be enough studies to warrant at least a preliminary meta-analysis. 


\section{2: Meta-Analysis Across Studies}

Meta-analysis is a set of quantitative techniques for evaluating and combining empirical results from different studies. Essentially one treats different point estimates of a given coefficient as individual observations. One can then use this vector of estimates to: estimate the underlying coefficient of interest, test the hypothesis that the coefficient is zero, and link the estimates to features of the underlying studies. Since there are currently a number of studies that have provided estimates of $\gamma$, the effect of currency union on trade, meta-analysis seems an appropriate way to summarize the current state of the literature. Stanley (2001) provides an excellent recent review and further references.

One begins meta-analysis by collecting as many estimates of a common effect as possible. To my knowledge, there are thirty-four papers that provide estimates of the effect of currency union on bilateral trade, which are denoted $\gamma$. I tabulate these in the appendix, along with the associated estimates of $\gamma$ (and its standard error) that seems to be most preferred or representative (if a preferred estimate is not available). While I have strong views about the value of some of these estimates (or lack thereof), I weigh each estimate equally, simply because there is no easily defensible alternative weighting scheme.

The most basic piece of meta-analysis is a test of the null hypothesis $\gamma=0$ when the thirty-four point estimates (and their standard errors) are pooled across studies. This classic test is due originally to Fisher (1932) and uses the p-values from each of the (34) underlying $\gamma$ estimates. Under the null hypothesis that each of the p-values is independently and randomly drawn from a normal $[0,1]$ distribution, minus twice the sum of the logs of the p-values is drawn from a chi-square. The hypothesis can be rejected at 
any standard significance level, since under the null hypothesis; the test-statistic of 1272 is drawn from chi-squared(68). ${ }^{3}$

I tabulate meta-estimates of the currency effect on trade in Table 1. I provide both "fixed effect" and "random effect" meta-estimates that are common in the area. The former are based on the assumption that a single fixed effect underlies every study, so that, in principle, if every study were infinitely large, every study would yield an identical result. This is the same as assuming there is no heterogeneity across studies. By way of contrast, the random effects estimator assume s that the studies are estimating different treatment effects, drawn from a distribution whose mean is of interest. ${ }^{4}$

Manifestly, there is considerable heterogeneity; the fixed and random effect estimators are not similar in magnitude. However, both estimates are both economically substantial; the smaller fixed effect estimate of $\gamma$ indicate that currency union raises trade by $33 \%$ (as $\ln (.29)-1=.33$ ), while the random effect estimate indicates that the effect is more like $90 \%$. Also, none of these conclusions change if my six studies are dropped; the test-statistic rejects the hypothesis of no effect, as under the null of no effect, 721 is drawn from chi-squared(54).

There is little indication that any single study is especially influential in driving these results. If the studies are omitted from the meta-analysis one by one, one finds the following (fixed-effect) point estimates for $\gamma$ (tabulated along with a 95\% confidence interval):

While I tried to choose the preferred/representative estimates to match the intentions of the authors, I did ... choose them. An alternative way to proceed is to use a more mechanical procedure to choose the underlying estimates of $\gamma$ for the meta-analysis. 
This is easy, since each of the underlying studies provides a number of individual $\gamma$ estimates. Thus, an alternative I now deploy is to use the median estimates of $\gamma$ from the underlying studies to construct an alternative set of $\gamma$ estimates (and associated standard errors) suitable for meta-analysis. I also use the estimates at the $25^{\text {th }}, 10^{\text {th }}$, and $5^{\text {th }}$ percentiles. ${ }^{5}$ Table 3 repeats the meta-analysis using these four alternative data sets. The default "preferred" estimates from table 1 are tabulated at the top to facilitate comparison.

The pooled meta-estimate of $\gamma$ falls as one moves away from the median estimate towards estimates that are lower within individual studies (by design). (It is also interesting - and reassuring - to note that the median estimates are higher than my preferred estimates!) But it is interesting to note that even using the $\gamma$ estimates taken from the $5^{\text {th }}$-percentile of each underlying study, the hypothesis of no effect of currency union on trade can be rejected at conventional significance level. Further, all the effects are economically substantive. The lower bound for the lowest estimate is .10, implying an effect of currency union on trade of over ten percent.

One might then ask which design features of the individual studies account for the differences across individual estimates of $\gamma$. It would be fun and interesting to explain the variation in $\gamma$ estimates across studies with a large number of study characteristics. Unfortunately, given the paucity of studies, it does not seem wise to use multivariate meta-regression techniques very intensively. Nevertheless, I report in Table 4a the results of a series of bivariate meta-regressions. Each row tabulates the intercept and slope coefficient from a different bivariate regression, where the regressand is the set of thirty-four $\gamma$ estimates, and the independent variable is listed at the left of the table. I then 
combine the most statistically significant variables together in some multivariate metaanalysis in Table 4b.

There are three interesting positive results in Table 4. First, there is not a positive relation between the number of observations and $\gamma$. The fact that there is no positive (let alone significant) relation between the sample size and the estimates of $\gamma$ raises a seriously worrying question as to whether the underlying empirical phenomenon is authentic (Stanley, 2001). Second, papers that I have co-authored have consistently higher point estimates of $\gamma$. Finally, papers that are focused on the Euro consistently find a lower effect of currency union on trade. That may occur because there is little data yet on the EMU era, or because the effect is indeed small. Time will tell.

To summarize: the meta-analysis indicates three strong, and one weak finding. First, the hypothesis that there is no effect of currency union on trade can be rejected at standard significance levels when the results from the individual studies are pooled.

Second, the pooled effect is not just positive but economically significant, consistent with the hypothesis that currency union raises trade by an economically significant amount. Third, studies that I have co-authored find a higher effect of currency union, while studies that focus on the Euro find a lower effect. Finally the preferred estimates of $\gamma$ from individual studies are not closely linked to most characteristics of the studies.

\section{3: Different Estimates of $\gamma$ and its Significance within Individual Studies}

Most of the thirty-four studies provide many different estimates of $\gamma$. For instance, my original paper provided over fifty estimates of $\gamma$ as a result of sensitivity analysis. In all, there are currently 754 estimates of $\gamma$ (but fewer associated t-statistics for 
the hypothesis of an insignificant $\gamma$, since these were not always provided). Simply averaging across the 754 estimates of $\gamma$ produces a mean of .86 ; the average $t$-ratio is $5.3{ }^{6}$ I provide a number of histograms of the various $\gamma$ estimates and their t-statistics in Figure 1. First, I provide histograms of all point estimates and their t-ratios at the top-left of the figure. That turns out to be rather uninformative given the presence of outliers; accordingly in the middle-left I provide analogues where $\gamma$ is restricted to lie in $(-2,2)$. At the bottom, I provide another pair of analogous graphs, restricting the range of $\gamma$ further to $(0,1.2)$. At the right of the figure I cut these data yet another way, and provide histograms of $\gamma$ (constrained to be between -2 and 2) estimated by myself and others.

What does the graphic show? The vast majority of the point estimates of $\gamma$ are positive; only 60 of the $754(<8 \%)$ are negative. Many are also economically large; 325 (43\%) exceed .69 in magnitude, a number that implies that currency union is associated with a doubling of trade, while 517 (69\%) exceed .22, implying that currency union increases trade by $25 \%$.

It is clear that many of the estimates are also statistically significant. The median t-statistic is 4.2 ; over three-quarters $(77 \%=479 / 626$ estimates with t-ratios) exceed 2. My t-ratios tend to be larger than those of others, but seventy percent $(=337 / 482)$ of the tstatistics of others are at least two (the median is 3.6).

Finally, one can also combine the different estimates that exist within the thirtyfour studies, on a paper-by-paper basis. Table 5 provides thirty-four rows (one for each study), which perform meta-analysis within the individual study to arrive at both fixedand random-effect estimates of $\gamma$. I also tabulate the p-values for the z-statistics which test the null hypothesis Ho: $\gamma=0$. The number of estimates provided by each study is 
tabulated, as is the p-value for a test of heterogeneity across the estimates (a low value indicates the presence of heterogeneity).

Table 5 clearly shows heterogeneity across $\gamma$ estimates. While only one is significantly negative (de Souza, fixed effects) and most are significantly positive, they vary considerably.

\section{4: Publication Bias}

The analysis above does not rely on published articles; indeed, fourteen of the thirty-four studies are circulating as working papers. Still, authors may be reluctant even to circulate work if they have certain results (e.g., results which corroborate the disputed currency union effect - or the reverse). Or, researchers with small sample size may pretest their results extensively to corroborate their preferred hypotheses. Thus, it is interesting to test for publication bias in this area.

I begin with "funnel plots" of gamma against its standard error, a standard tool for publication bias. One is searching for signs of asymmetry, indicating that studies with equal precision disproportionately find either small or large results. Asymmetry at the top of the graph, (where studies with high precision - low standard errors - are plotted) may give especially compelling evidence of publication bias.

The preferred estimates from the 34 studies are graphed in a funnel plot at the top left corner of Figure 2, and there is indeed evidence of asymmetry to the right of the plot, consistent with publication bias. This is less apparent in the funnel plot immediately below, which uses the number of observations on the ordinate instead of the inverse of the standard error, a different measure of precision. A different graphical detail, the 
"Galbraith plot" of the t-ratio for $\gamma$ against its standard error, is in the lower left corner of the figure. A regression line, constrained to go through the origin, is portrayed along with a $95 \%$ confidence interval, with slope equal to the overall gamma effect. The position of each study on the $\mathrm{x}$-axis indicates the weight allocated to it in meta-analysis. In the absence of heterogeneity, one would expect most studies to lie within the confidence interval. That is, there is again strong evidence of heterogeneity.

The other graphics in Figure 2 are funnel plots for different measures of gamma. At the top of the middle column, I use the within-study median estimates of $\gamma$, and below I use the estimates of $\gamma$ from the $25^{\text {th }}$ and $10^{\text {th }}$ percentiles within study (discussed above and analyzed in Table 3). At the top of the right column, I provide a funnel plot of the $5^{\text {th }}$ Percentile estimates. The median and $25^{\text {th }}$ percentile estimates indicate asymmetry to the right. The middle right funnel plot portrays all 626 estimates (those with standard errors). Since this is dominated by a few outliers, in the bottom right I constrain $\gamma$ to the range of $(-2,2)$. Again there is evidence of asymmetry to the right.

It seems there is visual evidence of publication bias from the funnel plots. This can be tested more rigorously with statistical tests which are analogues to various aspects of the visual funnel plots. Begg and Mazumdar (1994) test for publication bias by checking if gamma estimates are correlated with their variances. Egger et al (1997) focus on the intercept in a regression of gamma on its precision (the inverse of the standard error), and interpret significance as evidence of publication bias. In practice, the BeggMazumdar test delivers a tiny correlation which is insignificant at over the .9 level. This indication of publication bias is corroborated by the Egger et al test, which indicates significant bias (the intercept has a t-statistic over 4, significant at all conventional 
levels). It is interesting to note that this is true even if my studies are dropped; both the Begg- Mazumdar and Egger et al tests indicate publication bias. Further, if one replaces the preferred estimates with the within-study median estimates (or those from the other percentiles used above), the indications of publication bias persist. Finally, both tests indicate publication bias if one uses all the estimates of gamma from within the individual studies.

There is strong evidence of publication bias. This could occur for a number of reasons. The effect of currency union on trade is an intensely political issue, especially in Europe, the political preferences of researchers may well be affecting reported analysis.

\section{5: Conclusion}

I do not wish to overstate the results of a meta-analysis like this. Thirty-four studies sounds like a lot. But, the studies are dependent and not all of equal interest, two features that I have ignored above. The different estimates of this effect are heterogeneous both across and within studies, and cannot be linked to study features such as the sample size. There is persuasive evidence of publication bias. Thus it would be unreasonable for anyone to have too much confidence in the meta-analytic estimate of the effect of currency union on trade.

That said, a quantitative survey of the literature shows reasonably strong evidence that currency union has a positive effect on trade. When the estimates are examined collectively, this effect is large in terms of both economic and statistical significance, implying that currency union seems typically to be associated with a significant increase of trade, ranging from over $30 \%$ up to $90 \%$. 


\section{References}

Alberto Alesina, Robert J. Barro, and Silvana Tenreyro (2003) "Optimal Currency Areas" in NBER Macroeconomics Annual 2002.

Barr, David, Francis Breedon and David Miles (2003) "Life on the Outside" Economic Policy, 573-613.

Begg, C. B., Mazumdar, M. (1994) "Operating characteristics of a rank correlation test for publication bias" Biometrics 50, 1088-1101.

Bomberger, William A. (2002) "Decolonization and Estimates of the Time Series Effect of Currency Unions" unpublished University of Florida working paper.

Bun, Maurice J.G. and Franc J.G.M. Klaassen (2002) "Has the Euro Increased Trade?" Tinbergen Institute Discussion Paper TI 2002-108/2.

De Sousa, José and Julie Lochard (2003) "Do Currency Unions Solve the Border Effect Puzzle?" LESSOR/ROSES unpublished.

De Souza, Lúcio Vinhas (2002) "Trade Effects of Monetary Integration in Large, Mature Economies" A Primer on the European Monetary Union” Kiel Working Paper No. 1137.

De Nardis, Sergio and Claudio Vicarelli (2003) "Currency Unions and Trade: The Special Case of EMU" forthcoming Review of World Economics.

Estevadeoral, Antoni, Brian Frantz, and Alan M. Taylor (2003) "The Rise and Fall of World Trade, 1870-1939" Quarterly Journal of Economics 118-2, 359-407.

Fatás, Antonio and Andrew K. Rose (2001) "Do Monetary Handcuffs Restrain Leviathan? Fiscal Policy in Extreme Exchange Rate Regimes" IMF Staff Papers 47, 4061.

Egger, M., Smith, G. D., Schneider, M., Minder, C. (1997) "Bias in meta-analysis detected by a simple, graphical test" British Medical Journal 315, 629-634.

Fidrmuc, Jan and Jarko Fidrmuc (2003) "Disintegration and Trade" Review of International Economics 11(5), 811-829.

Fisher, R.A. (1932) Statistical Methods for Research Workers (4th ed.) London, Oliver and Boyd.

Flam, Harry, and Håkan Nordström (2003) "Trade Volume Effects of the Euro: Aggregate and Sector Estimates" IIES unpublished. 
Flandreau, Marc and Mathilde Maurel (2001) "Monetary Union, Trade Integration, and Business Cycles in $19^{\text {th }}$ Century Europe: Just Do It" CEPR Discussion Paper No. 3087.

Frankel, Jeffrey A. and Andrew K. Rose (2002) "An Estimate of the Effect of Currency Unions on Trade and Output” Quarterly Journal of Economics CXVII.2, 437-466.

Glick, Reuven and Andrew K. Rose (2002) "Does a Currency Union Affect Trade? The Time Series Evidence” European Economic Review 46-6, 1125-1151.

Honohan, Patrick (2001) “Discussion” Economic Policy 33, 457-461.

Kenen, Peter B. (2002) "Currency Unions and Trade: Variations on Themes by Rose and Persson” RBNZ DP/2002/08.

Klein, Michael W. (2002) 'Dollarization and Trade” NBER Working Paper 8879.

Levy Yeyati, Eduardo (2003) "On the Impact of a Common Currency on Bilateral Trade" Economics Letters

López-Córdova, J. Ernesto and Chris Meissner (2003) "Exchange-Rate Regimes and International Trade: Evidence from the Classical Gold Standard Era" American Economic Review 93-1, 344-353.

Melitz, Jacques (2001) “Geography, Trade and Currency Union” CEPR Discussion Paper No. 2987.

Melitz, Jacques (2002) "Language and Foreign Trade" unpublished University of Strathclyde working paper.

Micco, Alejandro, Ernesto Stein, Guillermo Ordoñez (2003) "The currency union effect on trade: early evidence from EMU” Economic Policy, 316-356.

Nitsch, Volker (2002a) "Comparing Apples and Oranges: The Trade Effect of Multilateral Currency Unions is Small” Bankgesellschaft Berlin unpublished.

Nitsch, Volker (2002b) "Honey, I Shrunk the Currency Union Effect on Trade" World Economy 25-4, 457-474.

Nitsch, Volker (2002c) "Have a Break, Have a ... National Currency: When do Monetary Unions Fall Apart?” Bankgesellschaft Berlin unpublished.

Pakko, Michael R. and Howard J. Wall (2001) "Reconsidering the Trade-Creating Effects of a Currency Union” FRB St. Louis Review 83-5, 37-45.

Persson, Torsten (2001) "Currency Unions and Trade: How Large is the Treatment Effect?” Economic Policy 33, 435-448. 
Ritschl, Albrecht and Nikolaus Wolf (2003) "Endogeneity of Currency Areas and Trade Blocs: Evidence from the Inter-War Period" Humboldt unpublished.

Rose, Andrew K. (2000) "One Money, One Market: Estimating the Effect of Common Currencies on Trade" Economic Policy 30, 9-45.

Rose, Andrew K. (2001) "Currency Unions and Trade: The Effect is Large" Economic Policy 33, 449-461.

Rose, Andrew K. (2004) "Do We Really Know that the WTO Increases Trade?" American Economic Review forthcoming.

Rose, Andrew K. and Charles Engel (2002) "Currency Unions and International Integration” Journal of Money, Credit, and Banking 34-4, 1067-1089.

Rose, Andrew K. and Eric van Wincoop (2001) "National Money as a Barrier to Trade: The Real Case for Monetary Union” American Economic Review 91-2, 386-390.

Saiki, Ayako (2002) "Common Currency as an Export Promoting Strategy" unpublished Brandeis University working paper.

Smith, Christie (2002) "Currency Unions and Gravity Models Revisited" RBNZ DP/2002/07.

Stanley, T.D. (2001) "Wheat from Chaff: Meta-Analysis as Quantitative Literature Review” Journal of Economic Perspectives 15-3, 131-150.

Subramanian, Arvind and Wei, Shang-Jin (2003) “The WTO Promotes Trade, Strongly but Unevenly" NBER Working Paper 10,024.

Tenreyro, Silvana (2001) "On the Causes and Consequences of Currency Unions" Harvard University unpublished.

Thom, Rodney and Brendan Walsh (2002) "The effect of a common currency on trade: Ireland before and after the sterling link" European Economic Review 46-6, 1111-1124. 


\begin{tabular}{|r|c|c|c|c|}
\hline & $\begin{array}{c}\text { Pooled Estimate } \\
\text { of } \boldsymbol{\gamma}\end{array}$ & $\begin{array}{c}\text { Lower Bound } \\
\text { of 95\% CI }\end{array}$ & $\begin{array}{c}\text { Upper Bound } \\
\text { of 95\% CI }\end{array}$ & $\begin{array}{c}\text { P-value for test } \\
\text { of no effect }\end{array}$ \\
\hline Fixed & .29 & .27 & .31 & .00 \\
\hline Random & .64 & .51 & .77 & .00 \\
\hline Fixed, without Rose & .22 & .19 & .24 & .00 \\
\hline Random, without Rose & .53 & .40 & .66 & .00 \\
\hline
\end{tabular}

Table 1: Meta-Analysis of Currency Union Effect on Trade $(\gamma)$

\begin{tabular}{|c|c|c|c|}
\hline Study Omitted: & Coefficient & 95\% CI, lower & 95\% CI, upper \\
\hline Rose & .28 & .26 & .30 \\
\hline Engel-Rose & .29 & .26 & .31 \\
\hline Frankel-Rose & .28 & .26 & .30 \\
\hline Rose-van Wincoop & .28 & .26 & .31 \\
\hline Glick-Rose & .27 & .25 & .29 \\
\hline Persson & .29 & .26 & .31 \\
\hline Rose & .26 & .24 & .29 \\
\hline Honohan & .29 & .26 & .31 \\
\hline Nitsch & .29 & .26 & .31 \\
\hline Pakko-Wall & .29 & .27 & .31 \\
\hline Walsh-Thom & .29 & .27 & .31 \\
\hline Melitz & .29 & .26 & .31 \\
\hline Lopez-Cordova and Meissner & .29 & .26 & .31 \\
\hline Tenreyro & .29 & .26 & .31 \\
\hline Levy Yeyati & .29 & .26 & .31 \\
\hline Nitsch & .29 & .26 & .31 \\
\hline Flandreau and Maurel & .26 & .24 & .29 \\
\hline Klein & .29 & .26 & .31 \\
\hline Estevadeoral, Frantz, and Taylor & .29 & .27 & .31 \\
\hline Alesina, Barro and Tenreyro & .29 & .26 & .31 \\
\hline Smith & .29 & .26 & .31 \\
\hline Bomberger & .30 & .28 & .32 \\
\hline Melitz & .28 & .26 & .30 \\
\hline Saiki & .29 & .26 & .31 \\
\hline Micco, Stein, Ordonez & .34 & .31 & .36 \\
\hline Kenen & .29 & .26 & .31 \\
\hline Bun and Klaassen & .29 & .26 & .31 \\
\hline de Souza & .29 & .27 & .31 \\
\hline de Sousa and Lochard & .28 & .26 & .30 \\
\hline Flam and Nordström & .35 & .33 & .38 \\
\hline Barr, Breedon and Miles & .29 & .27 & .32 \\
\hline de Nardis and Vicarelli & .30 & .28 & .33 \\
\hline Rose & .28 & .26 & .30 \\
\hline Subramanian-Wei & .28 & .26 & .30 \\
\hline Combined & .29 & .27 & .31 \\
\hline
\end{tabular}

Table 2: Sensitivity of Meta-Analysis of $\gamma$ to Individual Studies (Fixed Effects) 


\begin{tabular}{|r|r|c|c|c|c|}
\hline & & $\begin{array}{c}\text { Pooled } \gamma \\
\text { Estimate }\end{array}$ & $\begin{array}{c}\text { Lower Bound, } \\
\mathbf{9 5 \%} \mathbf{~ C I}\end{array}$ & $\begin{array}{c}\text { Upper Bound, } \\
\mathbf{9 5 \%} \text { CI }\end{array}$ & $\begin{array}{c}\text { P-value for } \\
\text { Ho: no effect }\end{array}$ \\
\hline "Preferred" & Fixed & .27 & .25 & .29 & .00 \\
\hline "Preferred" & Random & .64 & .51 & .76 & .00 \\
\hline Median & Fixed & .34 & .31 & .38 & .00 \\
\hline $\mathbf{2 5}^{\text {th }}$-Percentile & Fixed & .18 & .62 & 1.01 & .00 \\
\hline $\mathbf{2 5}^{\text {th}}$-Percentile & Random & .52 & .15 & .20 & .00 \\
\hline $\mathbf{1 0}^{\text {th}}$-Percentile & Fixed & .12 & .38 & .67 & .00 \\
\hline $\mathbf{1 0}^{\text {th}}$-Percentile & Random & .37 & .24 & .14 & .00 \\
\hline $\mathbf{5}^{\text {th}}$-Percentile & Fixed & .11 & .10 & .51 & .00 \\
\hline $\mathbf{5}^{\text {th }}$-Percentile & Random & .38 & .27 & .13 & .00 \\
\hline
\end{tabular}

Table 3: Sensitivity of Meta-Analysis of $\gamma$ to Choice of "Preferred" Estimate

\begin{tabular}{|r|c|c|}
\hline Study Characteristic & $\begin{array}{c}\text { Slope Coefficient } \\
(\mid \text { z-statistic } \mid)\end{array}$ & $\begin{array}{c}\text { Intercept } \\
(\mid \text { z-statistic } \mid)\end{array}$ \\
\hline Number of Observations in study & $8.0 \mathrm{e}-7(.9)$ & $.60(6.7)$ \\
\hline Focus on EMU Observations & $-.55(3.9)$ & $.79(10.6)$ \\
\hline Short-Run Focus & $-.42(2.6)$ & $.49(3.3)$ \\
\hline Standard Error of $\gamma$ & $.98(1.4)$ & $.54(6.9)$ \\
\hline Dummy for Rose as Author & $.46(2.8)$ & $.25(1.2)$ \\
\hline Dummy for mainly cross-section or panel study & $.46(2.2)$ & $.46(3.5)$ \\
\hline Number of Countries in study & $.001(1.6)$ & $.59(3.9)$ \\
\hline Number of Years in study & $.002(0.4)$ & $.74(3.0)$ \\
\hline Dummy for post-WWII study & $-.10(0.4)$ & \\
\hline
\end{tabular}

Table 4a: Meta-Analysis: Bivariate Determination of $\gamma$ Across Studies

\begin{tabular}{|r|c|c|}
\hline Study Characteristic & $\begin{array}{c}\text { Slope Coefficient } \\
(\mid z \text {-statistic } \mid)\end{array}$ & $\begin{array}{c}\text { Slope Coefficient } \\
(\mid z \text { ztstatistic } \mid)\end{array}$ \\
\hline Focus on EMU Observations & $-.57(2.8)$ & $-.50(4.0)$ \\
\hline Dummy for Rose as Author & $.40(2.6)$ & $.39(2.8)$ \\
\hline Dummy for mainly cross-section or panel study & $.19(1.0)$ & \\
\hline Short-Run Focus & $.14(0.7)$ & $.69(9.0)$ \\
\hline Intercept & $.50(2.9)$ & \\
\hline
\end{tabular}

Table 4b: Meta-Analysis: Multivariate Determination of $\gamma$ Across Studies 


\begin{tabular}{|c|c|c|c|c|c|}
\hline Study & & Coefficients & $\begin{array}{c}\text { Coeff }=0 \\
\text { (p-value) }\end{array}$ & $\begin{array}{c}\text { No. of } \\
\text { Estimates }\end{array}$ & $\begin{array}{c}\text { Heterogeneity } \\
\text { (p-value) }\end{array}$ \\
\hline Rose & $\begin{array}{c}\text { Fixed } \\
\text { Random }\end{array}$ & $\begin{array}{l}1.289 \\
1.311 \\
\end{array}$ & $\begin{array}{l}0.000 \\
0.000\end{array}$ & 52 & 0.00 \\
\hline Engel-Rose & $\begin{array}{c}\text { Fixed } \\
\text { Random }\end{array}$ & $\begin{array}{l}1.350 \\
1.350 \\
\end{array}$ & $\begin{array}{l}0.000 \\
0.000 \\
\end{array}$ & 5 & 0.78 \\
\hline Frankel-Rose & $\begin{array}{c}\text { Fixed } \\
\text { Random }\end{array}$ & $\begin{array}{l}1.631 \\
1.634\end{array}$ & $\begin{array}{l}0.000 \\
0.000\end{array}$ & 5 & 0.02 \\
\hline $\begin{array}{r}\text { Rose-van } \\
\text { Wincoop }\end{array}$ & $\begin{array}{c}\text { Fixed } \\
\text { Random }\end{array}$ & $\begin{array}{l}0.230 \\
0.649\end{array}$ & $\begin{array}{l}0.000 \\
0.000\end{array}$ & 18 & 0.00 \\
\hline Glick-Rose & $\begin{array}{l}\text { Fixed } \\
\text { Random }\end{array}$ & $\begin{array}{l}0.697 \\
0.772 \\
\end{array}$ & $\begin{array}{l}0.000 \\
0.000 \\
\end{array}$ & 37 & 0.00 \\
\hline Persson & $\begin{array}{c}\text { Fixed } \\
\text { Random } \\
\end{array}$ & $\begin{array}{l}0.647 \\
0.586 \\
\end{array}$ & $\begin{array}{l}0.000 \\
0.000 \\
\end{array}$ & 6 & 0.11 \\
\hline Rose & $\begin{array}{c}\text { Fixed } \\
\text { Random }\end{array}$ & $\begin{array}{l}0.824 \\
1.060 \\
\end{array}$ & $\begin{array}{l}0.000 \\
0.000 \\
\end{array}$ & 17 & 0.00 \\
\hline Honohan & $\begin{array}{c}\text { Fixed } \\
\text { Random }\end{array}$ & $\begin{array}{l}0.352 \\
0.356\end{array}$ & $\begin{array}{l}0.000 \\
0.052\end{array}$ & 12 & 0.00 \\
\hline Nitsch & $\begin{array}{c}\text { Fixed } \\
\text { Random }\end{array}$ & $\begin{array}{l}3.003 \\
1.551 \\
\end{array}$ & $\begin{array}{l}0.000 \\
0.000\end{array}$ & 83 & 0.00 \\
\hline Pakko-Wall & $\begin{array}{c}\text { Fixed } \\
\text { Random } \\
\end{array}$ & $\begin{array}{l}0.874 \\
0.332 \\
\end{array}$ & $\begin{array}{l}0.000 \\
0.350 \\
\end{array}$ & 6 & 0.00 \\
\hline Walsh-Thom & $\begin{array}{c}\text { Fixed } \\
\text { Random }\end{array}$ & $\begin{array}{c}-0.008 \\
0.020\end{array}$ & $\begin{array}{l}0.574 \\
0.542\end{array}$ & 7 & 0.00 \\
\hline Melitz & $\begin{array}{c}\text { Fixed } \\
\text { Random }\end{array}$ & $\begin{array}{l}1.888 \\
1.906 \\
\end{array}$ & $\begin{array}{l}0.000 \\
0.000 \\
\end{array}$ & 6 & 0.00 \\
\hline $\begin{array}{r}\text { Lopez-Cordova and } \\
\text { Meissner }\end{array}$ & $\begin{array}{c}\text { Fixed } \\
\text { Random }\end{array}$ & $\begin{array}{l}0.723 \\
0.722 \\
\end{array}$ & $\begin{array}{l}0.000 \\
0.000 \\
\end{array}$ & 47 & 0.38 \\
\hline $\begin{array}{r}\text { Silvana } \\
\text { Tenreyro }\end{array}$ & $\begin{array}{c}\text { Fixed } \\
\text { Random }\end{array}$ & $\begin{array}{l}0.803 \\
0.714 \\
\end{array}$ & $\begin{array}{l}0.000 \\
0.000 \\
\end{array}$ & 4 & 0.03 \\
\hline Levy Yeyati & $\begin{array}{c}\text { Fixed } \\
\text { Random }\end{array}$ & $\begin{array}{l}1.014 \\
1.055\end{array}$ & $\begin{array}{l}0.000 \\
0.000\end{array}$ & 19 & 0.02 \\
\hline Nitsch & $\begin{array}{c}\text { Fixed } \\
\text { Random }\end{array}$ & $\begin{array}{l}0.464 \\
0.429 \\
\end{array}$ & $\begin{array}{l}0.000 \\
0.009 \\
\end{array}$ & 8 & 0.00 \\
\hline $\begin{array}{r}\text { Flandreau and } \\
\text { Maurel } \\
\end{array}$ & $\begin{array}{c}\text { Fixed } \\
\text { Random }\end{array}$ & $\begin{array}{l}0.941 \\
0.903 \\
\end{array}$ & $\begin{array}{l}0.000 \\
0.000 \\
\end{array}$ & 8 & 0.00 \\
\hline Klein & $\begin{array}{c}\text { Fixed } \\
\text { Random }\end{array}$ & $\begin{array}{l}0.090 \\
0.370\end{array}$ & $\begin{array}{l}0.013 \\
0.047\end{array}$ & 25 & 0.00 \\
\hline $\begin{array}{r}\begin{array}{r}\text { Estevadeoral, Frantz, } \\
\text { and Taylor }\end{array} \\
\end{array}$ & $\begin{array}{c}\text { Fixed } \\
\text { Random }\end{array}$ & $\begin{array}{l}0.433 \\
0.450 \\
\end{array}$ & $\begin{array}{l}0.000 \\
0.000\end{array}$ & 18 & 0.01 \\
\hline $\begin{array}{r}\begin{array}{r}\text { Alesina, Barro and } \\
\text { Tenreyro }\end{array} \\
\end{array}$ & $\begin{array}{l}\text { Fixed } \\
\text { Random } \\
\end{array}$ & $\begin{array}{l}1.159 \\
1.649 \\
\end{array}$ & $\begin{array}{l}0.000 \\
0.000 \\
\end{array}$ & 8 & 0.00 \\
\hline Smith & $\begin{array}{c}\text { Fixed } \\
\text { Random }\end{array}$ & $\begin{array}{l}1.007 \\
1.118 \\
\end{array}$ & $\begin{array}{l}0.000 \\
0.000\end{array}$ & 17 & 0.00 \\
\hline Bomberger & $\begin{array}{c}\text { Fixed } \\
\text { Random }\end{array}$ & $\begin{array}{l}0.205 \\
0.315 \\
\end{array}$ & $\begin{array}{l}0.000 \\
0.006 \\
\end{array}$ & 6 & 0.00 \\
\hline Melitz & $\begin{array}{c}\text { Fixed } \\
\text { Random }\end{array}$ & $\begin{array}{l}1.312 \\
1.312 \\
\end{array}$ & $\begin{array}{l}0.000 \\
0.000 \\
\end{array}$ & 13 & 0.99 \\
\hline Saiki & $\begin{array}{l}\text { Fixed } \\
\text { Random }\end{array}$ & $\begin{array}{l}1.162 \\
0.520 \\
\end{array}$ & $\begin{array}{l}0.000 \\
0.008 \\
\end{array}$ & 16 & 0.00 \\
\hline Micco, Stein, Ordonez & $\begin{array}{c}\text { Fixed } \\
\text { Random }\end{array}$ & $\begin{array}{l}0.098 \\
0.130\end{array}$ & $\begin{array}{l}0.000 \\
0.000\end{array}$ & 54 & 0.00 \\
\hline
\end{tabular}




\begin{tabular}{|c|c|c|c|c|c|}
\hline Kenen & $\begin{array}{c}\text { Fixed } \\
\text { Random }\end{array}$ & $\begin{array}{l}1.081 \\
0.988\end{array}$ & $\begin{array}{l}0.000 \\
0.000\end{array}$ & 10 & 0.01 \\
\hline Bun and Klaassen & $\begin{array}{c}\text { Fixed } \\
\text { Random }\end{array}$ & $\begin{array}{l}0.330 \\
0.330\end{array}$ & $\begin{array}{l}0.000 \\
0.001\end{array}$ & 1 & $\mathrm{n} / \mathrm{a}$ \\
\hline de Souza & $\begin{array}{c}\text { Fixed } \\
\text { Random }\end{array}$ & $\begin{array}{l}-0.143 \\
-0.018\end{array}$ & $\begin{array}{l}0.000 \\
0.714\end{array}$ & 30 & 0.00 \\
\hline de Sousa and Lochard & $\begin{array}{c}\text { Fixed } \\
\text { Random }\end{array}$ & $\begin{array}{l}1.706 \\
1.698\end{array}$ & $\begin{array}{l}0.000 \\
0.000\end{array}$ & 14 & 0.00 \\
\hline Flam and Nordström & $\begin{array}{c}\text { Fixed } \\
\text { Random }\end{array}$ & $\begin{array}{l}0.150 \\
0.149\end{array}$ & $\begin{array}{l}0.000 \\
0.000\end{array}$ & 49 & 0.00 \\
\hline $\begin{array}{r}\text { Barr, Breedon and } \\
\text { Miles }\end{array}$ & $\begin{array}{c}\text { Fixed } \\
\text { Random }\end{array}$ & $\begin{array}{l}0.234 \\
0.234\end{array}$ & $\begin{array}{l}0.000 \\
0.000\end{array}$ & 2 & 0.44 \\
\hline $\begin{array}{r}\text { de Nardis and } \\
\text { Vicarelli }\end{array}$ & $\begin{array}{c}\text { Fixed } \\
\text { Random }\end{array}$ & $\begin{array}{l}0.090 \\
0.090 \\
\end{array}$ & $\begin{array}{l}0.000 \\
0.001\end{array}$ & 2 & 0.90 \\
\hline Rose & $\begin{array}{l}\text { Fixed } \\
\text { Random }\end{array}$ & $\begin{array}{l}0.905 \\
0.988\end{array}$ & $\begin{array}{l}0.000 \\
0.000\end{array}$ & 10 & 0.00 \\
\hline Subramanian-Wei & $\begin{array}{c}\text { Fixed } \\
\text { Random }\end{array}$ & $\begin{array}{l}1.142 \\
1.142\end{array}$ & $\begin{array}{l}0.000 \\
0.000\end{array}$ & 11 & 1.0 \\
\hline
\end{tabular}

Table 5: Within-Study meta-estimation of $\gamma$ 


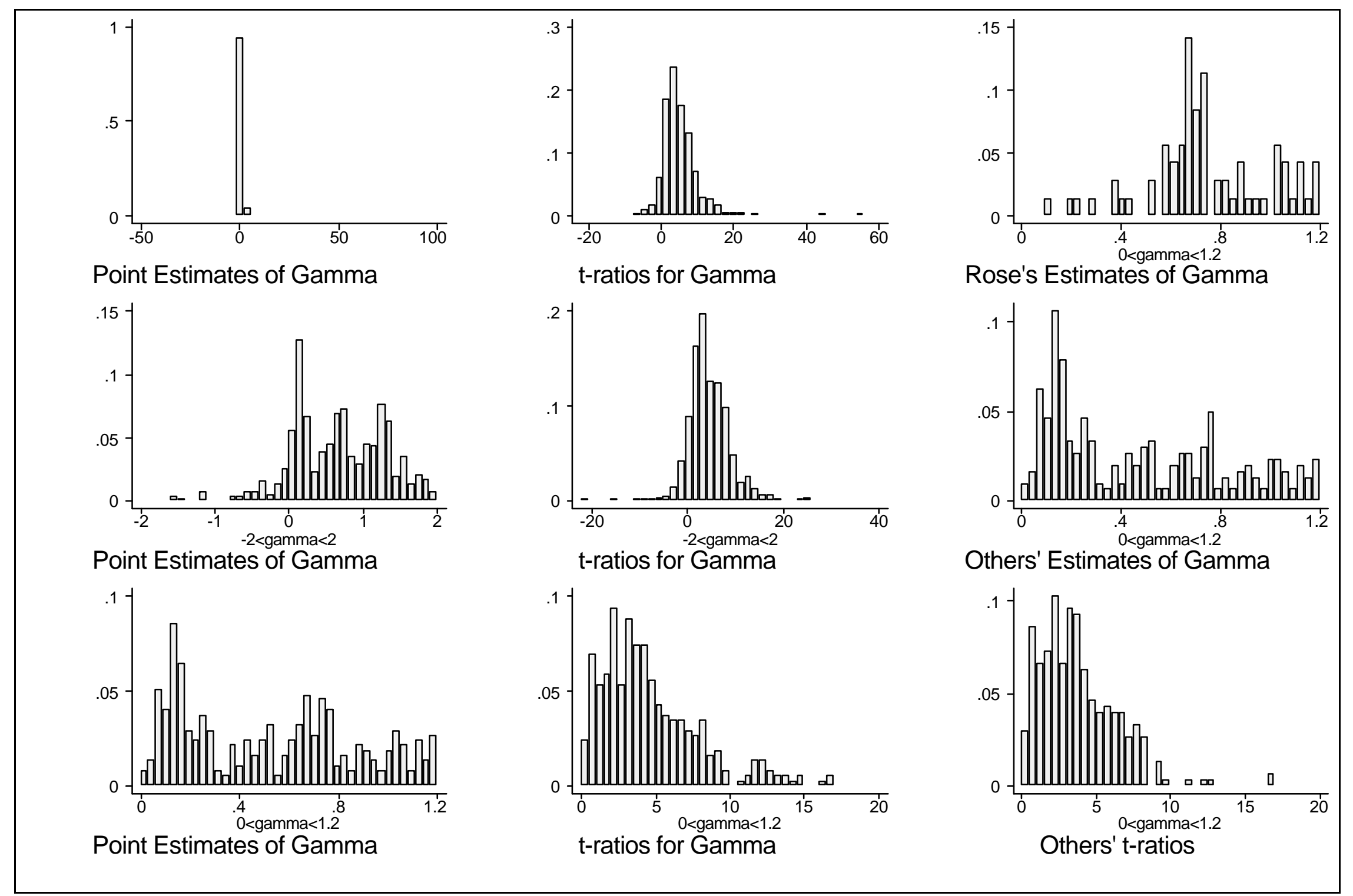

Figure 1: The Estimated Effect of Currency Union on Trade 


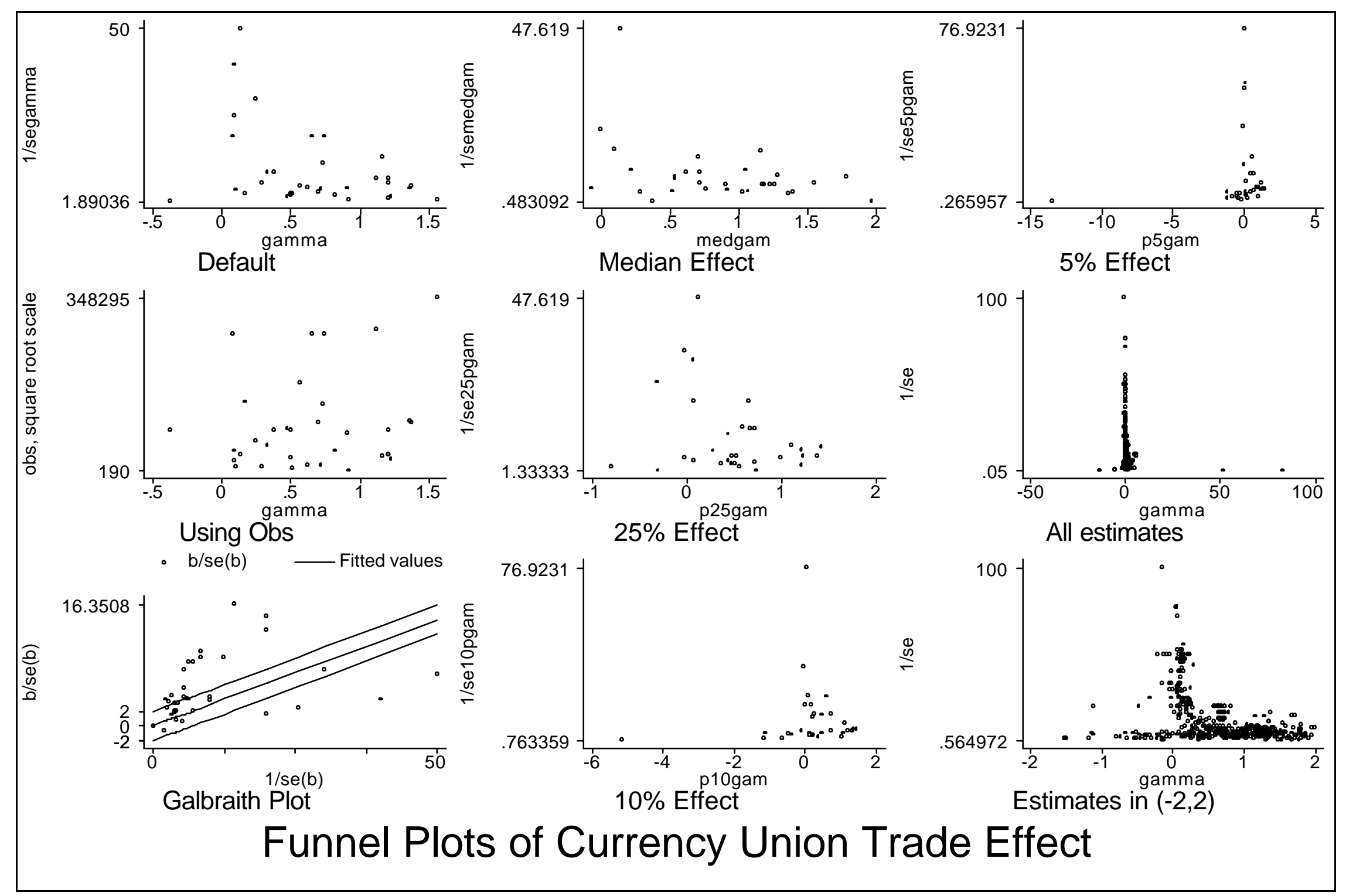

Figure 2: Funnel Plots for Publication Bias 
Appendix: Estimates of the Effect of Currency Union on Trade

\begin{tabular}{|l|c|c|c|}
\hline Author & Year & $\gamma$ & s.e. of $\gamma$ \\
\hline Rose & 2000 & 1.21 & 0.14 \\
\hline Engel-Rose & 2002 & 1.21 & 0.37 \\
\hline Frankel-Rose & 2002 & 1.36 & 0.18 \\
\hline Rose-van Wincoop & 2001 & 0.91 & 0.18 \\
\hline Glick-Rose & 2002 & 0.65 & 0.05 \\
\hline Persson & 2001 & 0.506 & 0.257 \\
\hline Rose & 2001 & 0.74 & 0.05 \\
\hline Honohan & 2001 & 0.921 & 0.4 \\
\hline Nitsch & $2002 \mathrm{~b}$ & 0.82 & 0.27 \\
\hline Pakko and Wall & 2001 & -0.378 & 0.529 \\
\hline Walsh and Thom & 2002 & 0.098 & 0.2 \\
\hline Melitz & 2001 & 0.7 & 0.23 \\
\hline López-Córdova and Meissner & 2003 & 0.716 & 0.186 \\
\hline Tenreyro & 2001 & 0.471 & 0.316 \\
\hline Levy Yeyati & 2003 & 0.5 & 0.25 \\
\hline Nitsch & $2002 \mathrm{a}$ & 0.62 & 0.17 \\
\hline Flandreau and Maurel & 2001 & 1.16 & 0.07 \\
\hline Klein & 2002 & 0.50 & 0.27 \\
\hline Estevadeoral, Frantz, and Taylor & 2003 & 0.293 & 0.145 \\
\hline Alesina, Barro and Tenreyro & 2003 & 1.56 & 0.44 \\
\hline Smith & 2002 & 0.38 & 0.1 \\
\hline Bomberger & 2002 & 0.08 & 0.05 \\
\hline Melitz & 2002 & 1.38 & 0.16 \\
\hline Saiki & 2002 & 0.56 & 0.16 \\
\hline Micco, Stein, Ordonez & 2003 & 0.089 & 0.025 \\
\hline Kenen & 2002 & 1.2219 & 0.305 \\
\hline Bun and Klaassen & 2002 & 0.33 & 0.1 \\
\hline de Souza & 2002 & 0.17 & 0.24 \\
\hline de Sousa and Lochard & 2003 & 1.21 & 0.12 \\
\hline Flam and Nordström & 2003 & 0.139 & 0.02 \\
\hline Barr, Breedon and Miles & 2003 & 0.25 & 0.033 \\
\hline de Nardis and Vicarelli & 2003 & 0.061 & 0.027 \\
\hline Rose & 2004 & 1.12 & 0.12 \\
\hline Subramanian-Wei & 2003 & 0.732 & 0.08 \\
\hline & & & \\
\hline
\end{tabular}

Estimates of $\gamma$ and standard error from $\ln ($ Trade $)=\gamma$ CurrencyUnion + controls + error 


\section{Endnotes}

1 Actually, make that many many others.

2 This also seems to be true of Ritschl and Wolf (2003), though the author is not able to grasp fully the subtlety of their paper which seems to use fixed exchange rates interchangeably with currency unions.

${ }^{3}$ Edgington's (1972) small sample correction leads to the same conclusion.

${ }^{4} \mathrm{http}: / / \mathrm{www}$. cochrane-net.org/openlearning/HTML/mod13.htm. To elaborate: the fixed effect assumption is that differences across studies are only due to within-study variation. By way of contrast, random effects models consider both between-study and within-study variability and assume that the studies are a random sample from the universe of all possible studies;

http://www.poems.msu.edu/InfoMastery/Overviews/steps_in_a_metaanalysis.htm. See also http://www.pitt.edu/ super1/lecture/lec1171/index.htm.

5 Thus, my initial study contains 52 estimates of $\gamma$. The median of these is 1.285 (with standard error of $.13)$. The $25^{\text {th }}$ percentile estimate is $1.1(.14)$; the $10^{\text {th }}$ percentile is $1.09(.26)$; and the $5^{\text {th }}$ percentile estimate is $.96(.15)$. If there is an even number of estimates in the underlying study, I choose the higher estimate when e.g., the median lies between two estimates. Three studies - Bun and Klaassen (2002), Barr et al (2003), and de Nardis and Vicarelli (2003) do not contain enough point estimates to allow them to be included in this exercise.

${ }^{6}$ For the 626 estimates with standard errors, the average estimate of $\gamma$ is 1.00 , again with an average $t$-ratio of 5.3. 